\title{
Water Security and Local People Sensitivity to Climate Variability and Change Among Coastal Communities in Zanzibar
}

\author{
Makame Omar Makame ${ }^{1} \&$ Richard Y.M. Kangalawe ${ }^{2}$ \\ ${ }^{1}$ School of Natural and Social Sciences, State University of Zanzibar, Tanzania \\ ${ }^{2}$ Institute of Resource Assessment, University of Dar es Salaam, Tanzania \\ Correspondence: Makame Omar Makame, School of Natural and Social Sciences, State University of Zanzibar, \\ Tanzania. Tel: 255-773-437-143. E-mail: maqam04@gmail.com
}

Received: January 28, 2018

Accepted: February 22, $2018 \quad$ Online Published: May 18, 2018

doi: $10.5539 /$ jsd.v11n3p23

URL: https://doi.org/10.5539/jsd.v11n3p23

\begin{abstract}
This paper presents one part of a larger, multidimensional study on the vulnerability of Zanzibar coastal communities to climate change and other stressors, focusing on water insecurity in two sites on the Zanzibar coast. Water security is composed of three components, namely water availability, water accessibility and the quality of available water. Findings from the study showed that water from wells is the major source of household water since tap water supply is often erratic. Farming systems are completely rain-fed, while some livestock owners use coral caves as the main source of water for their animals. Water quality is a major challenge along the coast as the majority of wells and coral caves in the study sites contain hard water with varying levels of salinity. A diversity of physical and social factors such as variability in water supply infrastructure, settlement structure, poverty, geology and geohydrology, variability in supply and poor water resource management adversely interact with local climate phenomena such as sea level rise, salt water incursion and drought to intensify water insecurity along the Zanzibar coast. Among the policy options to address these challenges would be to promote rainwater harvesting and increased utilisation of underground water for irrigation in the dry areas in order to increase agricultural production and reduce poverty.
\end{abstract}

Keywords: climate variability, climate change, coastal communities, vulnerability, water resources, water insecurity, Zanzibar

\section{Introduction}

The supply of fresh water has been declining globally and it is estimated that currently 1.6 billion people live in areas with high water scarcity and stress (UNEP, 2011). Moreover, this figure is expected to rise to 3 billion people by 2025 due to population increase and the desire for increasing agricultural output under multiple stressors (Arnell, 2004; Perveen and James, 2011; Hanjra and Qureshi, 2010). However, the scarcity and stress is unevenly distributed, with the poorest segments of the population who depend highly on water resources for their livelihoods often experiencing the most limited water supply (UNEP, 2011). For instance, small islands in the Pacific and Indian Ocean lack sufficient and permanent surface water in the form of big rivers or lakes and are fully reliant on rainfall and groundwater resources (Kuruppu, 2009; Mimura et al., 2007). The Zanzibar Islands are no exception and also rely heavily on the extraction of underground water for domestic and industrial uses and rainfall for agriculture (Gössling, 2001; Gössling et al., 2012). This makes them highly sensitive to the observed variability in climate and sea level rise and the predicted changes to both water quality and quantity (Sultan, 2011). While the Zanzibar Islands are considered to have rich aquifers compared to water demand (Halcrow, 1994), these freshwater aquifers are constantly under pressure due to expansion of tourism industry Gössling (2001), increasing demands for agriculture, poor water governance, low technology and poverty (Hansson, 2010; Kuruppu, 2009; Mortreux and Barnett, 2009). Indeed, in such islands there is a direct relationship between the volume of both underground and surface water and rainfall, and according to Mimura et al. (2007) a $10 \%$ reduction in average rainfall by 2050 in the Pacific would lead to a $20 \%$ reduction in the size of the freshwater lens on some areas. Other studies show that even current climate variability and extreme regional events such as drought attributable to ENSO events have triggered water scarcity and stress in the Pacific Islands (Kuruppu and Liverman, 2011; Kuruppu, 2009; Pelling and Uitto, 2001).

In Zanzibar, like many other small islands utilisation and management of water resources is part and parcel of 
the efforts towards eradication of poverty and reduce localised food shortage. It is also important in the implementation of the Sustainable Development Goals 2030, particularly SDG 1 on poverty, SDG 2 on zero hunger, and SDG 6 on clean water and sanitation set by the United Nations. This is mainly because increasing water reliability will increase agricultural output, allowing local people to escape from the food shortage trap and ultimately from poverty (UNEP, 2011; Hanjra and Qureshi, 2010). Although Zanzibar has done a lot to improve water accessibility and availability at least at the household level over the last decade (Hansson, 2010), in some coastal villages, particularly along the east coasts of both major islands, water supply remains erratic (Gössling, 2001). In addition, local people in these areas still depend on local sources such as wells and caves which are prone to contamination and affected by climate variability (Hansson, 2010; Kombo, 2011). This article therefore, identifies the main source of water for various uses in the study areas, examines current status of water security including the sensitivity of the local water resources to climate variability and sea level rise and current coping strategies. Water security as a concept has been defined extensively across disciplines as water is a cross cutting issue that cuts across various components of human welfare and survival (Cook and Baker, 2012; Gbadegesin and Olorunfemi, 2011; Bu-Chun et al., 2007). For the purpose of this study water security in Zanzibar coastal communities has been defined as accessibility and availability of quality water for household and food production needs.

\section{Study sites}

This study was conducted in Kiuyu Mbuyuni, in the north-eastern parts of Pemba Island, and Matemwe, in the north-eastern part of Unguja Island (Figure 1). The combination of these two islands forms the island nation of Zanzibar which is part of the United Republic of Tanzania, and located offshore Tanzania mainland coast. Both sites fall in the coral rag agroecological zone, which is less fertile than other agroecological zones and gets exhausted easily under minimum pressure and erratic water supply (Klein, 2008; Walsh 2009; Makame et al., 2015).
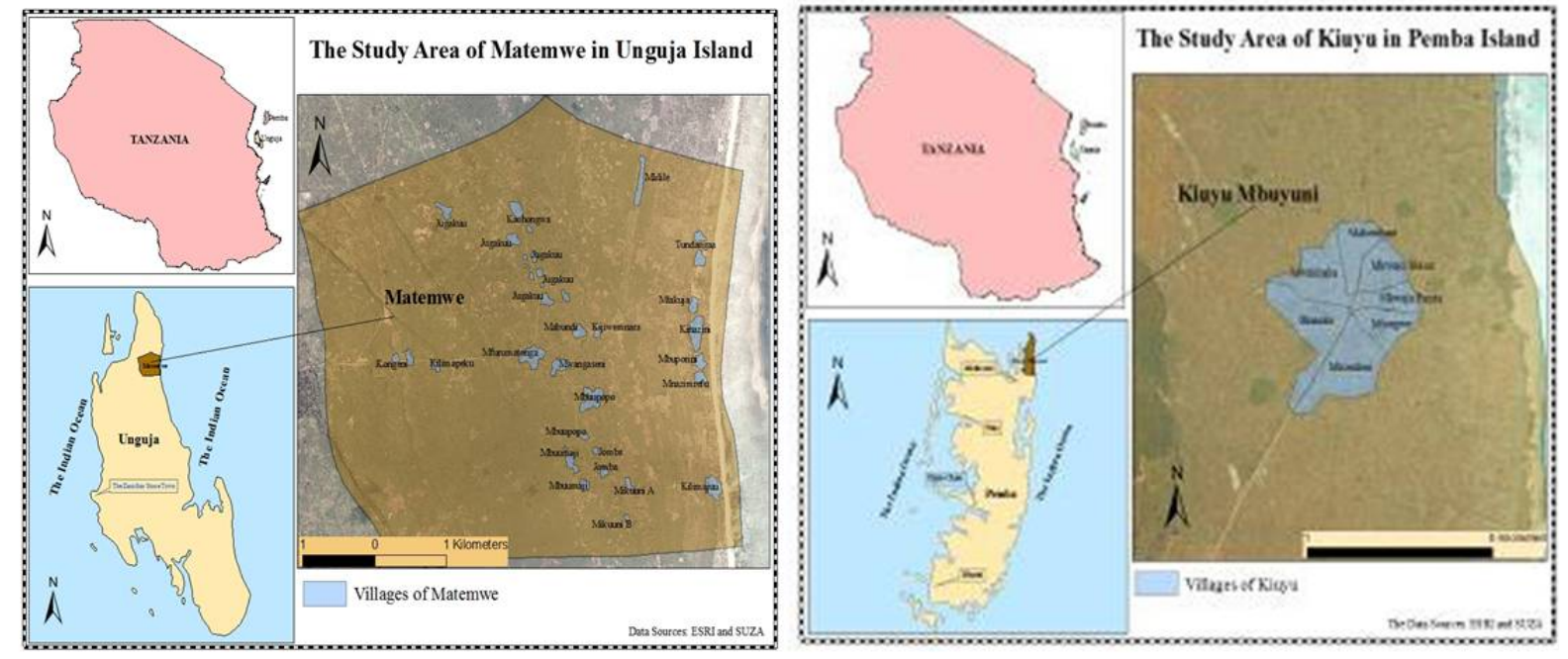

Figure 1. Study sites - Matemwe (left) and Kiuyu Mbuyuni (right)

The rainfall is unreliable and low compared with central and western corridors; the annual average along the east of both islands is around $1400 \mathrm{~mm}$, while the central and west corridors receive up to $2000 \mathrm{~mm}$ per annum on average (Walsh, 2009). Generally, Pemba Island receives more rainfall than Unguja with Unguja receiving more rainfall during the short rainy season (vuli), while the opposite applies for the long rainy season (masika) when Pemba receives more rainfall than Unguja (Figure 2).

As groundwater in these areas contains salt and may be easily affected by sea water intrusion even under minimum pressure, piped water is normally supplied from distant sources (Hansson, 2010). The hydrological cycle of oceanic islands like Zanzibar suggests that the depth of water lenses decreases as distance increases from the central, and thus, makes peripheries (along the shore) less resilient to sea level rise and associated sea water intrusion (Halcrow, 1994; Hansson, 2010). 


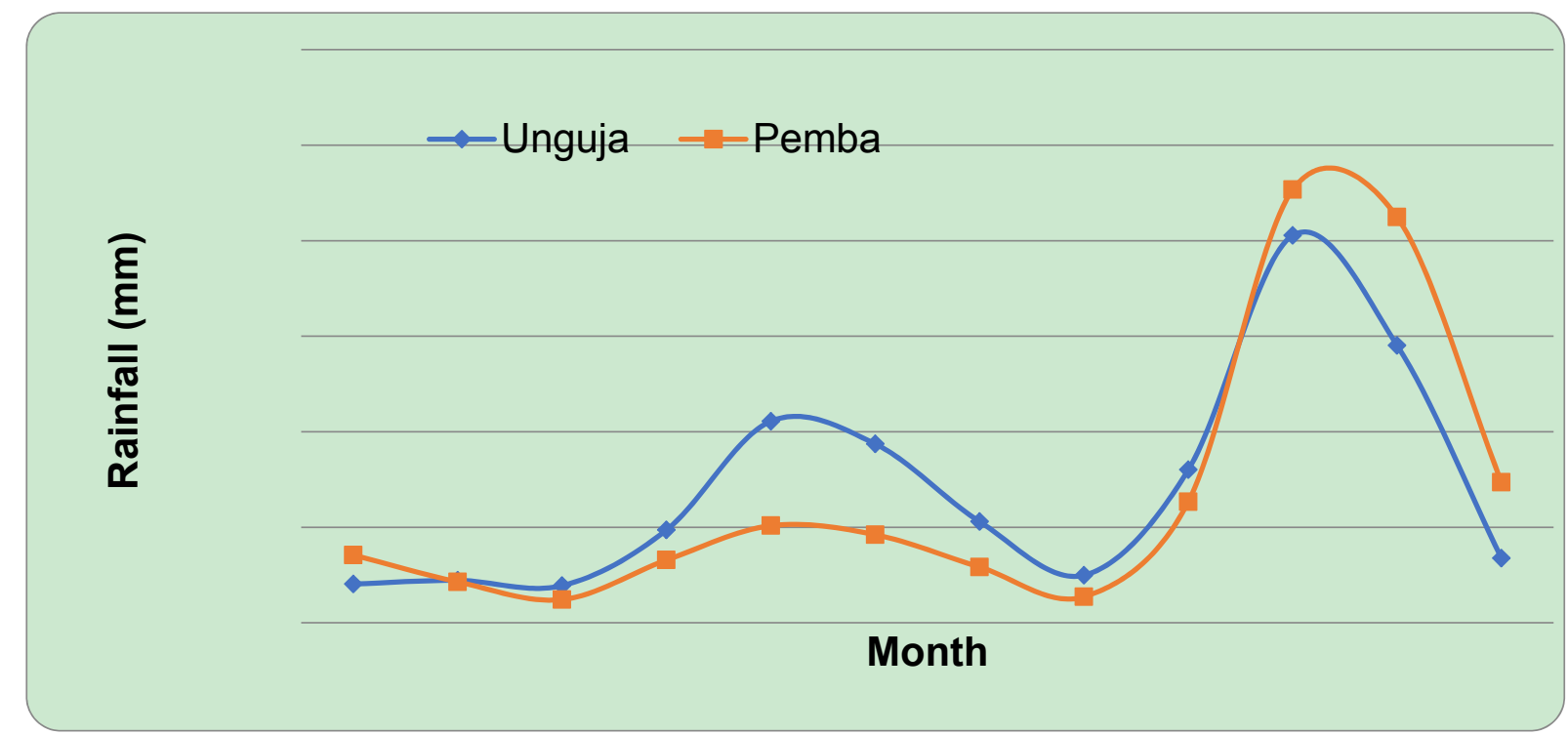

Figure 2. Monthly rainfall showing the two rainfall peaks for Zanzibar during the Vuli (left) and Masika (right)

Source: Makame et al. (2015)

\section{Methods}

The results reported in this paper form part of a study on the vulnerability of Zanzibar coastal communities to climate change and other stressors. The study used a variety of methods to triangulate findings. These included in-depth interviews, household survey, water resources inventories and secondary data. Firstly, the household's survey related to water security was administered to 200 households, 100 households from each site. Secondly, in-depth interviews were undertaken to collect information on the current trends in water availability, accessibility and quality. Sixteen local people were involved in the in-depth interviews, eight from each site including the local leaders known as sheha. Thirdly, the study conducted a water resources inventory at each site, where all local wells and caves were visited and depths of the wells were measured using rope and a measuring tape and the terrain of the coral caves was observed. Distance from the villages with easy access to community stand pipes to the nearest villages where water is readily available was calculated using ArcGIS to examine the water accessibility.

\section{Results and Discussion}

\subsection{Sources of Fresh Water across Sectors}

Data from the survey showed that $55 \%$ of the respondents in Kiuyu Mbuyuni used community taps for household needs, while in Matemwe $66 \%$ of the respondents used the local wells. None of the respondents was found using cave water for domestic use in Pemba site, whilst in Unguja site $11 \%$ of the respondents used caves for all of their water needs (Table 1). The results revealed that community taps are common sources of water for household needs in Kiuyu Mbuyuni, while community wells are a most common source in Matemwe. Local wells were reported by about $55 \%$ of respondents, whereas community taps accounted for $34.5 \%$ of respondents and ranked second as the most dependable water source. The nucleated nature of settlements in Kiuyu Mbuyuni seems to have facilitated the availability of tap water for the majority compared with Matemwe. However, across the sites the various local sources complement each other. These results are consistent with the study by Hansson (2010) in central and south east coast of Unguja which found that wells are a common water source for communities in those areas, supplemented by caves and community taps. 
Table 1. Percent responses on sources of water for domestic uses

\begin{tabular}{lccc}
\hline Sources of water & $\begin{array}{c}\text { Kiuyu Mbuyuni } \\
(\mathbf{n = 1 0 0 )}\end{array}$ & $\begin{array}{c}\text { Matemwe } \\
(\mathbf{n = 1 0 0})\end{array}$ & $\begin{array}{c}\text { Total } \\
(\mathbf{N}=\mathbf{2 0 0})\end{array}$ \\
\hline Local wells & 43 & 66 & 54.5 \\
Community taps & 55 & 14 & 34.5 \\
Coral caves & 0 & 11 & 5.5 \\
Tap on property & 2 & 9 & 5.5 \\
Total & 100 & 100 & 100 \\
\hline
\end{tabular}

None of the respondents in either site mentioned the utilisation of water directly from rainfall as main source, because rainfall is a seasonal phenomenon and villagers generally have no means to harvest and store it. However, local scale rainwater harvesting for short term uses in the household is common in Zanzibar. In most cases, small buckets are placed under the homestead roof to collect rainwater. Rainwater is perceived to be softer than well water and thus is mainly used for dish and clothes washing during rainy seasons (Hansson, 2010). This is contrary to other parts of Africa, for example in the rural areas of Oyo state of Nigeria where rainwater is an important source of portable drinking water (Gbadegesin and Olorunfemi, 2011). However, the major challenge is that local people in the study areas and in Zanzibar generally, are unable to preserve the rainwater in large quantity and make it safe for drinking for longer times.

At the same time crop farming across the sites, is entirely rain-fed, which makes it sensitive to climate variability and change. The unreliability of rainfall, in both quantity and distribution, coupled with poor soils is partly responsible for localised food shortage in the areas (Walsh, 2009). For instance, in Micheweni district, where Kiuyu Mbuyuni is located, 7000 people reported to have suffered from severe shortage of food in 2008-2011. This was caused by prolonged dry spells during this period (Said, 2011).

With regard to livestock, caves were reported to be the major source of water in Pemba Island while local wells were found to be a major source in Unguja Island. This could mainly be because in the sites in Pemba there are caves available within the grazing land. In Matemwe caves are mostly found in the southern part of the area. Livestock keeping has become part and parcel of a mixed farming system as a response to poor soil conditions. Indeed, cattle were reported to be kept as an asset and sold out during a family crisis. Thus, availability of rainfall for the growth of pasture and drinking water for animals is crucial for livestock keeping and arable farming, food security and livelihoods.

\subsection{Characterising Water Security}

\subsubsection{Water Availability}

Respondents were asked whether their main source of water was adequately available for all of their household's needs. The results in Table 2 show that more than half of respondents in Pemba site perceived that water from community taps was inadequately available for their needs. In Matemwe where most households reported to use water from wells as their main source of water, $71 \%$ also perceived an inadequate availability of water for household needs (Table 2). This corroborates with the findings in section 4.1 in which it was found that local sources of water (community taps, wells and caves) complemented each other across the sites. The study found that in areas where tap water is more erratic, water from taps is used only for drinking, while water from wells or caves is used for other purposes. This is because tap water is perceived to be safe and clean (Hansson, 2010).

Tap water was found to be irregularly distributed and erratic. However, comparing the two sites, Kiuyu Mbuyuni had a more regular supply than Matemwe despite the fact that the former received piped water from more distant sources (more than $10 \mathrm{~km}$ ), while the latter received from a source located at less than $3 \mathrm{~km}$. 
Table 2. Percentage responses on availability of water from various sources

\begin{tabular}{lccc}
\hline Sources of water & $\begin{array}{c}\text { Kiuyu Mbuyuni } \\
(\mathbf{n = 5 2 )}\end{array}$ & $\begin{array}{c}\text { Matemwe } \\
(\mathbf{n = 4 9 )}\end{array}$ & $\begin{array}{c}\text { Total } \\
(\mathbf{n = 1 0 1})\end{array}$ \\
\hline Local wells & 40 & 71 & 55.5 \\
Community taps & 56 & 13 & 34.5 \\
Tap on property & 4 & 10 & 7.0 \\
Coral caves & 0 & 6 & 3.0 \\
Total & 100 & 100 & 100 \\
\hline
\end{tabular}

Across the sites the pressure of pipe water decreased as distance increased from the main pipe increased. For example, it was found that out of the nine villages in Matemwe only two villages of Mwangaseni and Mbuyu Popo (Table 3) situated close to the main pipe received piped water regularly. Local people in this area claimed that tourism hotels and bungalows pump water from the main pipe and thus reduce the pressure from outlets that do not use additional pumps. A similar experience was reported in Kiuyu Mbuyuni where despite the compactness of settlements, piped water was also claimed to be available regularly in only two villages out of the seven, namely, Shanake and Mkondoni (Table 3). The low availability of tap water across the sites may thus be influenced by poor technology used by the villagers.

Table 3. Type and number of sources of water in the study areas by villages

\begin{tabular}{|c|c|c|c|c|c|}
\hline $\mathbf{S} / \mathbf{N}$ & Villages & Wells & Caves & Tap on property & Community taps \\
\hline \multicolumn{6}{|c|}{ Sources of water in Mateme, Unguja } \\
\hline 1 & Mwangaseni & 5 & 0 & 6 & 33 \\
\hline 2 & Kachongwa & 3 & 5 & 0 & 7 \\
\hline 3 & Mbuyu popo & 1 & 0 & 2 & 5 \\
\hline 4 & Mbuyu maji & 1 & 0 & 0 & 1 \\
\hline 5 & Jomba & 2 & 0 & 0 & 6 \\
\hline 6 & Juga kuu & 2 & 2 & 0 & 3 \\
\hline 7 & Kilima juu & 6 & 0 & 4 & 6 \\
\hline 8 & Mikuuni & 1 & 0 & 0 & 2 \\
\hline 9 & Tundangaa & 14 & 0 & 10 & 20 \\
\hline \multicolumn{6}{|c|}{ Sources of water in Kiuyu Mbuyuni } \\
\hline 10 & Shanake & 1 & & 14 & 6 \\
\hline 11 & Mwikibaba & 2 & & 2 & 7 \\
\hline 12 & Mkwaju panda & 1 & & 0 & 6 \\
\hline 13 & Mkwaju shauri & 1 & & 0 & 6 \\
\hline 14 & Mtongwe & 1 & & 1 & 5 \\
\hline 15 & Mkondoni & 2 & & 1 & 5 \\
\hline 16 & Makombani & 1 & & 0 & 7 \\
\hline
\end{tabular}

Source: Local leader register book. Note: Kiuyu Mbuyuni has more than 20 coral caves with water but located in inaccessible bushlands.

Local wells, which were found to be more reliable sources across the sites, are sensitive to drawing demand and dry conditions as volumes decline or the wells completely dry out during the normal dry season, or prolonged 
dry spells. Although a study by Halcrow (1994) showed that underground aquifers are only partially recharged by rainfall (7\% and $23 \%$ in Pemba and Unguja respectively), local people perceived rainfall as significant for the recharging of their wells. For instance, in Kiuyu Mbuyuni four wells out of nine (44.4\%), and three out of 35 $(8.6 \%)$ in Matemwe have a tendency to completely dry out during dry spells, while the volume of the remaining wells fluctuate depending on the intensity of dry spells. With the above data, Pemba Island appears to be more vulnerable to water insecurity given that nearly one half of the wells dry out during dry spells. The 1999-2000 and 2008-2010 dry spells were perceived to have had a significant impact on local water resources. This was also reported by Kombo (2011) from his study in southern parts of Unguja Island. Even springs that are run by Zanzibar Water Authority exhibit direct relationship between water production and seasonal variation of rainfall in recharging levels (Figure 2). The shallow depth of local wells coupled with poor geohydrology and unreliable rainfall along the eastern parts of the island, make these areas even more vulnerable to water insecurity.

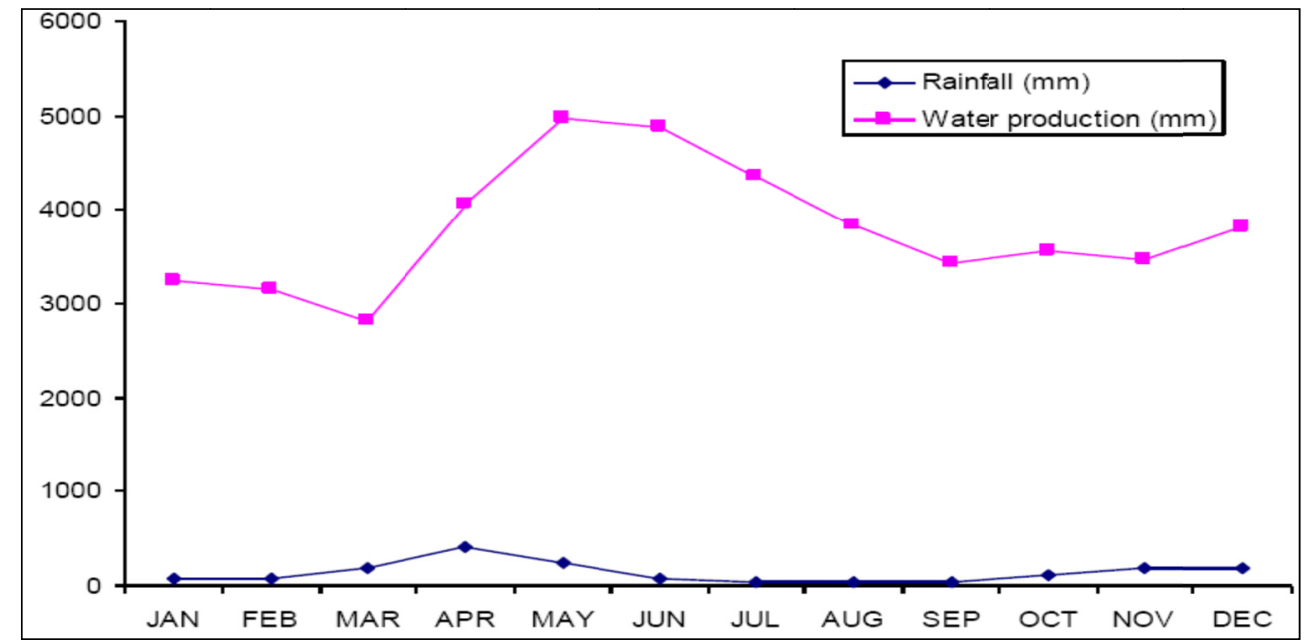

Figure 3. Relationship between rainfall and water production from Bububu spring, Unguja Island

Source: Kombo (2011:63)

In Matemwe site, Mbuyu Maji, Jomba and Mikuuni villages (Table 3) which are located in the furthest south from the main pipeline are continuously facing water irregularities as they depend solely on local wells that are sensitive to even normal dry condition. During a field visit undertaken as part of the study being reported here, villagers from Mikuuni village were found digging a second well in order to accommodate the ever increasing needs for water. Villages further south, namely, Kachongwa and Juga Kuu (Table 3) are less vulnerable because of the presence of caves which are less affected by dry spells than wells in terms of volume of water. Kilima Juu and Kandagaa villages, which are located along the shore close to the ocean, have a large number of wells compared to other villages (Table 3). Also, these wells experience less fluctuations in water volume, though most of them contain salty water and the salinity increases with increasing dry conditions or prolonged dry spells.

The majority of caves have large volumes of water and some of them contain fresh water with minimal salt content that can be used for domestic purposes and small scale irrigation. However, most of them are inaccessible except where water pumps are used as discussed in Section 4.2.2. In Matemwe, for example, there is one cave which supplies water to one of the hotels located along the beach, with an average cave yield of ' $480,000 \mathrm{~m}^{3} /$ year. Based on a calculation done by the Ministry of Water, Constitution, Energy, Lands and Environment (1995), this volume is enough to supply 37,600 people with water for a year, calculated on 35 litres/person/day (Hansson, 2010:24), . The cave that is used to supply water to the hotel in Matemwe could therefore supply the entire population of the area, which is about 6,381 based on Census results of 2012 (URT, 2013). In other parts of Zanzibar, especially along the southeast coast of Unguja, water from caves is supplied to the villages using pipes (Hansson, 2010).

\subsubsection{Water Accessibility}

The results in Table 1 showed that only $2 \%$ of the respondents in Kiuyu Mbuyuni used taps on their property as their main source water for household uses, whereas in Matemwe the corresponding proportion was $9 \%$. The results match with data obtained from local leaders which showed that in Kiuyu Mbuyuni only 18 households out of 1,548 households (1.2\%) had taps on their properties, whereas in Matemwe, 22 households out of 1,337 
(1.6\%) had taps on their properties. Thus the majority of villagers have to walk to look for water outside the homesteads on daily basis. Based on Hansson's (2010) findings on the east coast of Unguja, at 32.5 litres/person/day for all uses (bathing, washing, dish washing, drinking and cooking) and with an average household size of six, each household needs 195 litres/day. Otherwise the water usage would need to be scaled down only the basic need. If we take a standard 20 litres bucket this means a woman would need to walk back and forth to the collection point (well, community tap, cave) 10 times per day in order to get 195 litres. It is obvious that this process uses a lot precious time that could be invested in other livelihood activities for reducing poverty.

Women are most vulnerable to water inaccessibility, as in most cases they are responsible for collecting water for household uses. This is reflected in the following quote from a woman from Mbuyu Popo village in Matemwe: "The well is far from here and our nearest cave has rough slopes and thus it is difficult to fetch water out of it. We are facing difficulties as I have to also go for seaweed farming, looking for firewood and fetching water daily".

Using ArcGIS the distance from the centre of each village to the points with working water taps was calculated. The results showed that in Kiuyu Mbuyuni the average distance covered to Shanake and Mkondoni villages to where tap water is available was $548 \mathrm{~m}$, whereas in Matemwe the average distance to village Mwangaseni and Mbuyu Popo where water is readily available was $1600 \mathrm{~m}(1.6 \mathrm{~km})$. However, the distance to water sources increases with increasing distance from the centre of the village. For instance, in Matemwe women from Mikuuni village (Table 3), which had only one well during the time of this study, had to walk for up to $2.3 \mathrm{~km}$ to look for tap water, especially during dry spells. While the well in this village was reported to be very old, dating back to Portuguese colonisation in Zanzibar between $16^{\text {th }}$ and $17^{\text {th }}$ centuries, its volume was claimed to be highly sensitive even under normal dry conditions. These results are consistent with other studies elsewhere. For example, in rural Zimbabwe, local people are reported to cover more than $500 \mathrm{~m}$ to the nearest water source, spending more than 30 minutes per trip (Gbadegesin and Olorunfemi, 2011). This ultimately reduces time for other activities and 'impacts the health of the people carrying water as in mostly cases carried on the head (Gbadegesin and Olorunfemi, 2011:490).

Although, caves in most cases contain a considerable amount of water as discussed in Section 4.2.1, most of them are inaccessible. For instance, in Matemwe site only one out of six caves was reported to be accessible, as its terrain allowed someone to walk into and fetch water from inside. The remaining caves needed water pumps in order to be able to access water from them. Poverty and poor rural electrification limit this option for most local communities. The nature of the rock and water resource ownership impacts the accessibility of water in Zanzibar coastal villages. For instance, Mlilile area in Kachongwa village has a water pump that was donated to the village by one Islamic organisation from town. After seeing people's suffering from water insecurity, this organisation provided a water pump, black pipes, tanks and a generator in order to pull out the water easily from one of the caves that had more fresh water compared to what the community was using. However, the community reported to be struggling in getting money for fuel to run the generator. As one respondent remarked, the money obtained from fishing was not enough for the household needs let alone buying fuel for the generator to run the water pump. In Kiuyu Mbuyuni where caves are the main source of water for livestock (Table 3), almost all of the caves are also inaccessible. Livestock keepers in this area use various means such as using ladder to get into the cave to fetch water for their animals.

\subsubsection{Quality of the Available Water}

While water supplied by pipe is perceived to be clean and fresh, water from wells and caves was claimed to be hard. Local people perceived that salinity in the water from both caves and wells was increasing with increasing temperature and decreasing rainfall. This has also been highlighted by Okello et al. (2015) in Lamu, Kenya and underground water study done by Halcrow in Zanzibar (Halcrow, 1994). In addition, the distance from the shore also sometimes influences the quality of water, for instance $57 \%$ of wells in Matemwe which are located within $100-200 \mathrm{~m}$ from the shoreline contain high concentration of salinity compared with wells at the upper parts of the shehia/ward. In Kiuyu Mbuyuni local people also perceived that the salt content in their water had increased in relation to increasing temperature and decreasing rainfall. Furthermore, most of the caves across the sites contain water with varying hardness. In Kiuyu Mbuyuni out of more than 20 caves, local people believed that only one or two caves contained fresh water, but they were inaccessible unless water pumps were used. The remaining caves contain considerable amount of salt and thus, only used for livestock.

Most of the caves in Kiuyu Mbuyuni are located within a short distance from the ocean contrary to Matemwe and some of them are tidal. The following testimony from a woman in Matemwe (Kachongwa Village) confirms 
the perceptions of the local community on the salinity content of water in the caves: "Water from this cave has high content of salt in such a way that sometimes we do not add salt while cooking especially in the dry season, we also drink the same water as we have no option, pipes are empty, located at distant places and we are failing to draw water from the other cave which has fresh water as it is inaccessible and we had no money for the generator's fuel to run water pump".

Livestock keepers from Kiuyu Mbuyuni village claimed that there were no impacts of salty water on the productivity of cattle (milk and meat). However, a scientific study may be needed to examine whether there is a relationship between the perceived decline of livestock productivity in these areas and increasing concentration of salt in cave water. Elsewhere in the world, for instance, in Canada beef cattle were diagnosed with disorder after being exposed to saline well water, mainly related to sulphates rather than sodium ions (Beke and Hironaka, 1991; Patterson and Johnson, 2003).

The findings related to increasing salinity content in ground water tallied with Kombo (2011) around Jozani Chwaka Bay National Park, and Hansson (2010) in the east coast of Unguja. Hansson (2010), for example, reported that $66 \%$ of the respondents perceived increased salt content in the local water sources. Other water problems identified included inadequate water quantity and bad smells. Similarly, the study by Halcrow (1994) revealed seasonal variations in salinity content even in the boreholes run by the Zanzibar Water Authority, which in both islands are located far from the ocean. Moreover, a study by Okello et al. (2015) found that sea level rise and climate change impacted both volume and salinity concentration on Shela aquifer, in Lamu, Kenya. Interviews with key informants revealed also that across the sites, waterborne diseases such as diarrhoea and cholera were common. Concerns about frequent outbreaks of water borne diseases including cholera, particularly during high rainfall seasons or extreme flood events, is reported to be due to contamination of the drinking water (Global Climate Adaptation Partnership, 2012). The results from the local leaders' register book showed that 90\% of the household in Kiuyu Mbuyuni had no latrine while compared to $74 \%$ of the households in Matemwe.. This is yet another factor that may be impacting the quality of water in local water sources. Local wells along the shore in Matemwe are particularly vulnerable to contamination due to their shallow depth.

\section{Conclusion}

Despite the reported achievement in rural water supply in Zanzibar, the study found that most communities in the study areas depended more on local sources of water such as wells and coral caves as they are most reliable sources of water for household needs. However tap water complement with local wells for the household needs. Livestock keeping is highly dependent on wells and caves for drinking water for the animals and rainfall for pasture growth. Crop farming is completely rainfed, which makes it vulnerable to climate variability and change. The availability and accessibility of quality water is also not uniform across the study areas, which confirms communities experienced water insecurity both at household and farming level. Communities with fewer local sources of water (wells and caves), and which are sensitive to climate variability and seasonality, are more vulnerable to water insecurity. Further, even without climate variability and change availability and accessibility of quality water across the sites is already affected by natural factors such hydrogeology and development challenges such as poverty. These factors together enhance the water insecurity challenge among the people in the study areas. Reducing water insecurity and bringing in a general improvement of livelihoods in Zanzibar coastal villages may be achieved by increasing accessibility to quality fresh water for household uses and farming. In addition, despite the observed variability of rainfall, there is a significant potential for rainwater harvesting for the above mentioned uses, which could be promoted through subsidies to obtain big water storage facilities. Apart from improving water availability, rainwater harvesting would most likely to improve both water and food security at the household level, and will help communities to cope and adapt to water insecurity associated with projected future climate change in Zanzibar.

\section{References}

Arnell, N. W. (2004). Climate change and global water resources: SRES emissions and socio-economic scenarios. Global Environmental Change, 14, 31-52. https://doi.org/10.1016/j.gloenvcha.2003.10.006

Beke, G. J., \& Hironaka, R. (1991). Toxicity to beef cattle of sulphur in saline well water: A case study. Science of the total environment, 101(3), 281-291. https://doi.org/10.1016/0048-9697(91)90042-D

Bu-chun, L., Xu-rong, M., Yu-zhong, L., \& You-lu, Y. (2007). The connotation and extension of agricultural water resources security. Agricultural Sciences in China, 6(1), 11-16. https://doi.org/10.1016/S1671-2927(07)60011-X

Cook, C., \& Bakker, K. (2012). Water security: Debating an emerging paradigm. Global Environmental Change, 
22(1), 94-102. https://doi.org/10.1016/j.gloenvcha.2011.10.011

Gbadegesin, A. S., \& Olorunfemi, F. B. (2011). Sustainable technological policy options for rural water supply management in selected rural areas of Oyo State, Nigeria". Management of Environmental Quality: An International Journal, 22(4), 486-501. https://doi.org/10.1108/14777831111136081

Global Climate Adaptation Partnership. (2012). The economics of climate change in Zanzibar: Chapter 4. Vulnerability, Impacts and Adaptation. Technical Report. UKAID.

Gössling, S. (2001). The consequences of tourism for sustainable water use on a tropical island: Zanzibar, Tanzania. Journal of Environmental Management, 61, 179-191.

Gössling, S., Peeters, P., Hall, C. M., Ceron, J., Dubois, G., La Vergne, L., \& Scott, D. (2012). Tourism and water use: Supply, demand, and security. An international review. Tourism Management 33, 1-15. https://doi.org/10.1016/j.tourman.2011.03.015

Halcrow. (1994). The development of water resources in Zanzibar. Final report. Revolutionary Government of Zanzibar, Zanzibar, Tanzania.

Hanjra, M. A., \& Qureshi, M. E. (2010). Global water crisis and future food security in an era of climate change. Food Policy, 35(5), 365-377. https://doi.org/10.1016/j.foodpol.2010.05.006

Hansson, E. (2010). Groundwater on Zanzibar - use and pollutants, Institutionen för växt- och miljövetenskaper, $\begin{array}{lllll}\text { Göteborgs } \quad \text { universitet. } & \text { Retrieved } & \text { July 2016, } & \text { from }\end{array}$ http://www.bioenv.gu.se/digitalAssets/1322/1322530_erik-hansson.pdf

Klein, R. (2008). The edaphic landscape of Unguja Island, Zanzibar: An exploratory study on the relationship between soil variability and landscape 85 p. Turku University Department of geography Publications, B: 11, Digipaino, Turku.

Kombo, K. A. (2011). Effects of climate change and variability on freshwater quantity and availability: A case study of Jozani-Chwaka Bay National Park - Zanzibar (Unpublished master's thesis). University of Dodoma, Tanzania.

Kuruppu, N. (2009). Adapting water resources to climate change in Kiribati: The importance of cultural values $\begin{array}{lllll}\text { and meanings. Environmental Sciences \& Policy, } & \text { 12(7), }\end{array}$ https://doi.org/10.1016/j.envsci.2009.07.005

Kuruppu, N., \& Liverman, D. (2011). Mental preparation for climate adaptation: The role of cognition and culture in enhancing adaptive capacity of water management in Kiribati. Global Environmental Change, 21(2), 657-669. https://doi.org/10.1016/j.gloenvcha.2010.12.002

Makame, M. O., Kangalawe, R. Y. M., \& Salum, L. A. (2015). Climate change and household food insecurity among fishing communities in the eastern coast of Zanzibar. Journal of Development and Agricultural Economics, 7(4), 131-142.

Mimura, N., Nurse, L., McLean, R.F., Agard, J., Briguglio, L., Lefale, P., Payet, R., \& Sem, G. (2007). Small islands. Climate Change (2007). Impacts, Adaptation and Vulnerability. Contribution of Working Group II to the Fourth Assessment Report of the Intergovernmental Panel on Climate Change, Parry, M.L., Canziani, O.F., Palutikof, J.P., van der Linden, P.J., and Hanson, C.E., (Eds.), Cambridge University Press, Cambridge, UK, 687-716.

Mortreux, C., \& Barnett, J. (2009). Climate change, migration and adaptation in Funafuti, Tuvalu. Global Environmental Change, 19(1), 105-112. https://doi.org/10.1016/j.gloenvcha.2008.09.006

Okello, C., Antonellini, M., Greggio, N., \& Wambiji, N. (2015). Freshwater resource characterization and vulnerability to climate change of the Shela aquifer in Lamu, Kenya. Environ Earth Sci, 73, 3801-3817.

Patterson, T., \& Johnson, P. (2003). Effects of water quality on beef cattle. Range Beef cow symposium. Paper Number 63. Retrieved June 4, 2015, from http://digitalcommons.unl.edu/rangebeefcowsymp/63

Pelling, M., \& Uitto, J. I. (2010). Small island developing states: Natural disaster vulnerability and global change. Environmental Hazards, 3(2), 49-62. https://doi.org/10.1016/S1464-2867(01)00018-3

Perveen, S., \& James, L.A. (2011). Scale invariance of water stress and scarcity indicators: Facilitating cross-scale comparisons of water resources vulnerability. Applied Geography, 31(1), 321-328. https://doi.org/10.1016/j.apgeog.2010.07.003

Said, S. (2011, May 5). Ukame, mabadiliko ya tabianchi na umaskini Pemba, mwananchi. Retrieved April 10, 
2015 , from http://www.mwananchi.co.tz/magazines/26-jungukuu/11650-ukame-mabadiliko-ya-tabianchi-na-umaskinipemba.html

SMZ. (2009). Zanzibar human development report 2009: Towards pro poor growth, in agriculture sector in Tanzania and its mitigation measure. Revolutionary Government of Zanzibar, Zanzibar, Tanzania.

Sultan, A. (2011, September, 28). Zanzibar rising sea level erodes fertile arable lands. Daily news online edition. Retrieved April 20, 2015, from http://www.dailynews.co.tz/home/?n=24048\&cat=home

UNEP. (2011). Ecosystem for water and food security. International water management institute. Retrieved May 21, 2012, from http://www.unep.org/pdf/DEPI-ECOSYSTEMS-FOOD-SECUR.pdf

United Republic of Tanzania - URT. (2013). Population and housing census, Population Distribution by Administrative Areas 2012. The United Republic of Tanzania, Dar es Salaam, Tanzania. Retrieved May 1, 2015, from http://nbs.go.tz

Walsh, M. T. (2009). The use of wild and cultivated plants as famine foods on Pemba Island, Zanzibar. Etudes Ocean Indien, special issue: Plantes et societies dans I'ocean occidental, 42/43, 217-241. Retrieved June 3, 2015, from http://oceanindien.revues.org/793

\section{Copyrights}

Copyright for this article is retained by the author(s), with first publication rights granted to the journal.

This is an open-access article distributed under the terms and conditions of the Creative Commons Attribution license (http://creativecommons.org/licenses/by/4.0/). 